\title{
EQUALITY IN PROCESS: COMMUNITY LAND DISPUTE RESOLUTION MECHANISMS IN KENYAN LAW
}

\author{
KATHRYN E. WITCHGER
}

"There are opportunities even in the most difficult moments." - Wangari Maathai ${ }^{l}$

\section{INTRODUCTION}

In 2010, Kenya ratified a Constitution that formalized its traditional dispute resolution mechanisms ("TDRMs"). ${ }^{2}$ In 2016, the legislature extended TDRM formalization to community land through the Community Land Act. ${ }^{3}$ While these mechanisms give greater voice to communities, ${ }^{4}$ they are implemented through local leaders, ${ }^{5}$ usually limited to

(C) 2018 Witchger. This is an open access article distributed under the terms of the Creative Commons Attribution License, which permits the user to copy, distribute, and transmit the work provided that the original author and source are credited.

* J.D., Columbia Law School; B.S.F.S., Georgetown University; D.E.A.S.C., l'Institut des Etudes Politiques. My deepest gratitude to Katarina Pistor for her insight and guidance. A special thanks to the International Senior Lawyers Project, Jonah Mgnola, Melba Wasunna, the research team at Strathmore Extractives Industry Centre, the Kerio Valley Community Organisation, and the people of Kerio Valley for their support, guidance, and teamwork. My appreciation to Janet Witchger for her edits and insight.

1 Wangari Muta Maathai, Unbowed: A Memoir 144 (2007).

2 See Constitution art. 159 (2010) (Kenya).

3 Community Land Act, No. 27 (2016) Kenya Gazette Supplement No. 148 § 39; see also National Land Commission Act (2015) Cap. 5D § 5; Land Act (2016) Cap. 280 § 4; Land Adjudication Act (2016) Cap. 284 $\S 4$.

4 Constitution art. 174(c) (2010) (Kenya) (noting one object of the new governmental system is "to give powers of self-governance to the people and enhance the participation of the people in the exercise of the powers of the State and in making decisions affecting them.").

5 Elin Henrysson \& Sandra F. Joireman, On the Edge of the Law: Women's Property Rights and Dispute Resolution in Kisii, Kenya, 43 Law \& Soc'y Rev. 39, 47 (2009); Pkalya et al., Indigenous Democracy: Traditional Conflict Resolution Mechanisms, at iv (Betty Rabar \& Martin Karimi eds., 2004). 
male elders, ${ }^{6}$ and do not adequately represent marginalized groups. ${ }^{7}$ During a typical land dispute, it is the elders that resolve the matter because they have the respect of the community, and the best memory for the boundaries of the land. ${ }^{8}$ They will call a "baraza" or gathering in which community members will have a chance to voice their opinions and furnish relevant evidence before the elders make a decision. ${ }^{9}$ In practice, this means that the new laws run the risk of formalizing not only TDRMs, but also unequal participation in these important mechanisms. While this Note focuses on the gendered impact of TDRMs, disparate access to TDRMs has a particular impact on unmarried women, youth, and other marginalized groups. ${ }^{10}$ The formalization of TDRMs is important because land is crucial to Kenyans: it is "not merely a factor of production; it is first and foremost, the medium which defines and binds together social and spiritual relations within and across generations." ${ }^{11}$ It is also a primary source of long-term investment. ${ }^{12}$ Thus, as TDRMs gain power in Kenya,

6 Collins Odote, The Legal and Policy Framework Regulating Community Land in Kenya: An Appraisal 15; see also infra Section I.A.3.

7 Fikret Berkes, Devolution of Environment and Resources Governance, 37 Envtl. Conservation 489, 492-93 (2010) (observing the marginalized are not represented in "local decision making bodies" under governments that have devolved powers); Perpetua Wambui Karanja, Women's Land Ownership Rights in Kenya, 10 Third World Legal Stud. 109, 121 (1991) (noting land adjudication is derived from the "patrilineal nature" of land inheritance therefore, "[w] omen were neither represented in the adjudication committees nor did they participate in the adjudication committee meetings.").

8 Burnette C. Fish \& Gerald W. Fish, Kalenjin Heritage 262-63 (1995). This is not the only form of TDRM in Kenya, but the forms are similar. See, e.g., Celestine Nyamu-Musembi, Local Norms, Institutions, and Women's Property Rights in Rural Kenya, 9 East Afr. J. Peace \& Hum. Rts. 255, 261-263 (2003) (describing dispute resolution in the Makueni District).

9 Laurence Juma, Reconciling African Customary Law and Human Rights in Kenya, 14 St. Thомаs L. REV. 459, 505 (2002) (“[D]isputes are generally adjudicated by local elders, chief councils (popularly known as the Barazas).").

10 See Plo Lumumba \& Luis G. Franceschi, The Constitution of Kenya, 2010: An Introductory COMMENTARY 263 (2014) ("Women generally held secondary rights or interest in land, and these were for uncertain durations subject to change and dependent on the maintenance of good relations with the clan, family or person through whom they obtained their access to land ....”).

11 Id. at 264 (citing Commission of Inquiry into the Land Law System of Kenya; Report of the Commission of Inquiry into the Land Law System of Kenya on Principles of a National Land Policy Framework; Constitutional Position of Land and New Institutional Framework for Land Administration (2002)).

12 Kenyan WallStreet, 62.8\% of Kenyans Prefer Investment in Land \& Real Estate - Survey, THE KENYAN WALl StreEt (Jan. 29, 2018), https://kenyanwallstreet.com/62-8-kenyans-prefer-investment-land-real-estatesurvey/ [https://perma.cc/DL2S-3J6U]; James Ngunjiri, Most Kenyan Workers Invest in Real Estate and Land for Retirement, Business DAILY (Jan. 29, 2018), https://www.businessdailyafrica.com/markets/marketnews/ Most-Kenyan-workers-invest-in-real-estate/3815534-4283574-67q191z/index.html [https://perma.cc/L9E2- 
there is a risk that the law will embed disparate treatment into the social, political, and legal fabric of a country that has sought to redefine itself in equality.

Kenyan land law formalizes TDRMs and embeds discriminatory practices through the complicated interaction of formal and informal (or customary) laws. ${ }^{13}$ Institutional theorists often view formal and informal as both fixed bodies ${ }^{14}$ and path dependent entities that are difficult to change. ${ }^{15}$ Conventional institutionalist literature has entrenched these views into proposed solutions to property problems in Africa. ${ }^{16}$ This Note will critically examine these theories and argue instead that Kenya is in a moment of institutional fluidity that gives communities in particular a chance to create inclusive TDRMs. ${ }^{17}$

5PK3]; Land Ownership and Hunger, Global Policy Forum, https:/www.globalpolicy.org/world-hunger/ land-ownership-and-hunger.html [https://perma.cc/3ZVR-DV6L] ("Unfair distribution and lack of access to land are key explanations for poverty and hunger.’).

13 This Note will use the term "informal" to describe the particular set of rules and structures that find their roots before colonialism. This is for ease of use because both institutional and legal theories use the term. However, it is important to note that "informal" has many negative connotations and would not be used if there were another term. Juma, a Kenyan law scholar, states that it is harmful to create a dichotomy between formal and informal law and name a certain type of law "informal," because it runs the risk of framing it as inferior. Juma further proposes the use of "African Customary Law"; however, this term both generalizes Kenyan law as encapsulating African law and still contains the term "customary," which also can have negative connotations. See Juma, supra note 9, at 460.

14 See Douglass C. North, Institutions, Institutional Change, and Economic Performance 4 (1990) (explaining the essential differences between formal and informal institutions); Celestine Itumbi Nyamu, Achieving Gender Equality in a Plural Legal Context, 15 Third World Legal Stud. 21, 27 (2000) (arguing in part that "the existence and coherence of customary law as a category is taken for granted, as is its antiquity, authenticity and historical continuity”). Contra Friedrich A. HayeK, Law, Legislation and Liberty (1973) (arguing formal law developed from informal law).

15 See Simon Deakin et al., Legal Institutionalism: Capitalism and the Constitutive Role of Law 2 (Univ. of Cambridge Faculty of Law Research Paper, 2015).

16 See generally Paul Collier, The Bottom Billion: Why the Poorest Countries are Failing and What Can Be Done About It (2007) (arguing that certain conditions in countries create the lock-in effect of path dependency that prevents poorer countries from developing); Angus Maddison, The West and the Rest in the World Economy: 1000-2030, 9 WorLD ECON. 75 (2008) (arguing that certain early policies created a path that over time has led to the divergence of the west and "the rest"); NoRTH, supra note 14, at 7 (creating a theory of institutional change and growth premised on the existence of path dependency and institutional "lock-in"); Hernando de Soto, The Myth of Capital: Why Capitalism Triumphs in the West and Fails Everywhere Else (2000) (arguing in part that the private property rights that developed in the West created a better institutional path).

17 TDRMs are different across time and space in Kenya. This Note will focus on the TDRMs used by the Kalenjin ethnic group in Western Kenya and other similar groups. See Francis Kariuki, Conflict Resolution by 
Kenya is at a crossroads. During colonialism, the British government expropriated the best land and Kenyans were regarded as tenants on the land. ${ }^{18}$ When the country became independent, it was bestowed with a Constitution that the people of Kenya neither drafted nor ratified. ${ }^{19}$ During the intervening years, the Constitution was amended many times in an attempt to centralize political and land-based power. ${ }^{20}$ These constitutional developments disregarded "the sanctity of the Constitution through disobedience to constitutional principles coupled with constant mutilation of the document .... [This] created a legal vacuum, which has led to the trivialization of Constitution making in Africa." ${ }^{21}$ In 2010, a new Constitution was ratified which vastly restructured the political landscape and empowered Kenyans through the devolution of political and land-based power. Six years have passed, yet there are persistent ambiguities between formal and informal land laws. ${ }^{22}$ The Community Land Act of 2016 is an attempt to formalize tenure on land that government officials historically expropriated. ${ }^{23}$ Yet as recently as the end of 2016, several significant legal and institutional changes have already been repealed. ${ }^{24}$ These changes do not simply

Elders in Africa: Successes, Challenges and Opportunities 4, http://www.kmco.co.ke/attachments/article/162/ Conflict $\% 20$ Resolution $\% 20$ by\%20Elders\%20successes, $\% 20$ challenges $\% 20$ and $\% 20 \% 20 \% 20 \% 20 \% 20$ opportunities-1.pdf [https://perma.cc/AUA3-28PN] (showing differences in conflict resolution across time); FiDA Kenya, Report on Traditional Justice Systems in Kenya: A Study of Communities in Coast Province 8 (2010) (noting traditional adjudication mechanisms "vary from community to community and have various names given to them").

18 Lumumba \& Franceschi, supra note 10, at 264-265.

19 Id. at 30.

$20 I d$. at $30-41$.

21 Id. at 48.

22 Catherine Boone et al., Land Politics under Kenya's New Constitution 2 (London Sch. of Econ. \& Pol. Sci. Dep't of Int'l Dev., Working Paper No. 16-178, 2016) ("The Constitution and the Land Acts thus set the stage for a contentious politics of institution-building and reform that would be shaped by conflicts of interest and power [sic] struggles."); see also Henrysson \& Joireman, supra note 5, at 52 (noting there are so many institutions that there is "ambiguity and inconsistency in . . understanding official dispute resolution channel[s]" and how they fit with TDRMs).

23 Boone et al., supra note 22, at 7-8 (finding that the government often expropriates community land); see also Liz Alden Wiley, The Community Land Act: Now It's Up to Communities, StAR (Sept. 17, 2016) http:// www.the-star.co.ke/news/2016/09/17/the-community-land-act-now-its-up-to-communities_c1420295 [https:// perma.cc/Q3RK-MKVZ] (stating that the Community Land Act is a failed attempt to clarify community land laws).

24 The Constitution had significantly bolstered the use of TDRMs through the devolved County Land Management Boards, which in some counties were made up of both elders and experts to oversee land disputes directly. These boards employed formal and informal law. However, the National Land Commission Act 2016 
impact scholastic legal analysis and development theory. Land matters have a real, lasting, and immediate impact on the lives of all Kenyans, ${ }^{25}$ especially the estimated sixty-five percent in rural areas. ${ }^{26}$ This is a critical moment in Kenyan history. How the government and communities choose to define the interaction of formal and informal land laws will have a lasting impact on equal participation and equal outcomes in TDRMs. ${ }^{27}$

This Note endeavors to illuminate two interdependent issues: First, it addresses the formalization of discrimination in TDRMs under community land legislation. ${ }^{28}$ Second, the Note shifts the scholarly lens Western legal and economic theorists use to analyze the interaction of formal and informal institutions in Africa. ${ }^{29}$ The two matters are interdependent because solutions are derived from the framework in which the problem is viewed. Therefore, in order to develop innovative solutions to discrimination, it is necessary to shift the way in which the problem is characterized. Part I examines the community land regime in Kenya and institutional theory. Part II addresses the formalization of TDRMs and discriminatory practices in land laws, and the failure of conventional institutionalist

revision clawed back the powers of the Commission and dissolved the Boards. Constitution art. 67 (2010) (Kenya); National Land Commission Act (2015) Cap. 5D § 5; National Land Commission Act (2012) Cap. 5D $\S \S 5(1)(f), 18(9)(b)$.

25 National Land Commission v. Attorney-General (2014) S.C.K. Advisory Opinion No. 2, paras. 97-150 ("Land, as a factor in social and economic activity in Kenya, has been a subject of constant interest, and of controversy, especially from a political standpoint.”).

26 Boone et al., supra note 22, at 2 ("Today, an estimated $65 \%$ live in the rural areas, and agriculture accounts for $30 \%$ of GDP. Land pressure is acute for smallholders and pastoralists, due to a vector of forces that includes a long history [of] land grabbing on the part of the rich and powerful, starting with colonial expropriations in the early 20th century and continuing under successive postcolonial regimes, demographic pressure on the land, rising land values, forest destruction and conservation, wildlife conservation efforts, and the slow growth of non-farm rural livelihoods and jobs.").

27 Patricia G. Kameri-Mbote, I Want it and I Want it now, Perspectives, Sept. 2013, at 6, 9 ("New land laws and policies are being enacted in different countries across the continent. Such contexts provide valuable openings to deal with discrimination against women and ensure that women's voices are heard in land management and governance.").

28 This analysis will take place within the realm of the land laws in Kenya, however it is important to note that this is one interpretation of the land laws where many are possible because "[p]oorly drafted legislation has created overlapping, unspecified, and conflicting mandates." Boone et al., supra note 22, at 10.

29 This Note will focus on economic and legal scholarship in the field of institutionalism. See, e.g., NorTH, supra note 14, at 9 (arguing that Third World countries are creating monopolistic institutional frameworks that curb development); see generally Gani Aldashev et al., Formal Law as a Magnet to Reform Custom, 60 Econ. Dev. \& Cultural Change 795 (2012) (arguing small changes in the law are more likely to lead to sustainable changes); Deakin et al., supra note 15 (arguing in part that legal institutions are path dependent). 
theory to adequately frame the problem. Finally, Part III proposes a new lens to interpret Kenyan land institutions and solutions for the legislature, ministries, non-governmental organizations, and the community.

\section{Kenyan Law and an Interpretive Theory}

Kenyan law is at a moment of change. The 2010 Constitution and the 2016 Community Land Act recognize and formalize community-owned land. However, the various levels of dispute resolution mechanisms are still contested spaces because the 2010 Kenyan Constitution and subsequent land laws created a new plural legal context of formal and informal land dispute resolution mechanisms..$^{30}$ Section I.A. will provide a framework for understanding and interpreting the many changes occurring. It will describe the formal land laws under the new Constitution and the informal land TDRMs that are common to many groups, with particular attention to the Kalenjin people of Kerio Valley in Western Kenya. ${ }^{31}$ These formal and informal means of land dispute resolution connect in a variety of ways: generally, through the various provisions of the Constitution and legislation that call for the use of TDRMs ${ }^{32}$ and, specifically, in Land Adjudication Committees, ${ }^{33}$ and Community Land Management Committees. ${ }^{34}$ Section I.B. gives an explanation of institutional theory

30 It is important to note that while the two are interconnected, informal mechanisms continue to vary across time and space. See Tamar Ezer, Forging a Path for Women's Rights in Customary Law, 27 Hastings Women's L.J. 65, 69-70 (2016) (stating that TDRMs are "not a fixed body of formally classified and easily ascertainable rules"); see also Catherine Muyeka Mumma, Kenya Legal and Ethical Issues Network on HIV \& Aids, Accessing Justice and Protecting the Rights of the Vulnerable Through Cultural Structures: A TOOL ON WorKING wITH Elders IN COMMUNITIES 2, http://kelinkenya.org/wp-content/uploads/2010/10/Workingwith-Cultural-Structures-A4FINAL [https://perma.cc/2FQT-TEJU] ("[C]ultural aspects that come into play on any issue ... vary from community to community. Even in a community they may vary from one family to another.").

31 This is with regard to unpublished research conducted by a team consisting of the International Senior Lawyers Project, the Kenyan National Commission on Human Rights and Strathmore Extractive Industries Centre on the governance structures of the Tugen and Keiyo (sub-tribes of the Kalenjin) of Kerio Valley. Further detailed ethnographies and analyses of customary law and procedure within different groups in Kenya are greatly needed in order to understand the complex influence that the new Constitution will have on the country as a whole.

32 See, e.g., Constitution art. 159(2)(c) (2010) (Kenya); Community Land Act, No. 27 (2016) KenyA Gazette Supplement No. 148 § 39; National Land Commission Act (2015) Cap. 5D § 5; Land Act (2016) Cap. 280 § 4; Land Adjudication Act (2016) Cap. 284 § 4.

33 Land Adjudication Act (2016) Cap. $284 \S 4$.

34 Community Land Act, No. 27 (2016) Kenya Gazette Supplement No. $148 \S 15$ (establishing the Community Land Management Committees). 
as a means to interpret and influence change in plural legal contexts.

\section{A. A History of Kenyan Land Law}

Historically, TDRMs began with elders who governed a usufructuary property system. ${ }^{35}$ Elders served an important function as both regulators of the environmental capacity and keepers of the communal land. ${ }^{36}$ These elders and clan leaders had authority over land and women held "secondary rights" to the land. ${ }^{37}$ With the introduction of a colonial system, the elder's TDRMs began to exist alongside statutory law as formal and informal came together through the office of Chief, who was included in land decisions as a local administrator for the colonial government. ${ }^{38}$ During the twentieth century, the colonial government also began to survey and demarcate many parcels of land. ${ }^{39}$ The resulting mixture of land at various stages of obtaining title created a system with many overlapping dispute resolution processes. While those on untitled community land still used TDRMs, these TDRMS were subordinated to the "received" British law. ${ }^{40}$ The result was a disempowerment of the elders and TDRMs. Meanwhile, women's role in the TDRMs remained tertiary to that of the elders and chiefs. Women's role was pushed to the bottom of a pyramid with elders and chiefs above, and the colonial government governing all.

35 A usufructuary property system is one in which the land is communal, but certain people are authorized to use parts of the land for certain purposes. See Derrick J. Thom \& Niels L. Martin, Ecology and Production in Baringo-Kerio Valley, Kenya, 73 Geographical Rev. 15, 22 (1983) (stating that these elders determined the allocation of land to individuals for cultivation and the areas for pastures or fallowing).

36 See id. at 22 (stating the importance of elders in land decisions).

37 Lumumba \& Franceschi, supra note 10, at 263 ("In pre-colonial times, communities in Kenya had their own legal systems of land based on their own customs and practices. The chiefs, elders and clan leaders were in charge of enforcing these systems. Land tenure systems were community: communities shared their land under the authority and advice of community elders and claim leaders.").

38 Chiefs are local officials of the national government who often help resolve local disputes. See Chiefs' Act (2012) Cap. $128 \S \S 6,7$ (stating that a chief can rely on community members to carry out his functions); see also Emma Elfversson, Peace from Below: Governance and Peacebuilding in Kerio Valley, Kenya, 54 J. Mod. Afr. Stud. 469, 474-75 (2016) (discussing the post-colonial period in the Kerio Valley); Simon Coldham, The Effect of Registration of Title Upon Customary Land Rights in Kenya, 22 J. Afr. L. 91, 95 (1978) (explaining that while the chief had the power of the national government, land sales only occurred with the consent of the elders).

39 See generally Coldham, supra note 38 (describing the land registration process from colonization onward).

40 Lumumba \& Franceschi, supra note 10, at 264-265. 
Colonialism also set into motion a system of land ownership predicated on one group taking from others, ${ }^{41}$ a practice which continued for much of Kenya's history. ${ }^{42}$ After independence in 1963, women continued to suffer under land policy. The many land statutes created a confusing network of over seventy-five laws that used customary rights and formal mechanisms to confer land ownership to men. ${ }^{43}$ Shortly before the 2010 Constitution was ratified, the Ministry of Lands released a sessional paper that identified a significant "lack of accountability in land governance leading to irregular allocations of public land." ${ }^{44}$ It is precisely these irregularities that colored the current legal and political framework of land dispute resolution processes. They led to the 2010 Constitution, which incorporated community participation directly into land management and mandated the Community Land Act of 2016 to protect the most vulnerable land. ${ }^{45}$ The Community Land Act, in particular, allows a group of people to own land communally, in much the same way as the usufructuary property system before colonialization, but with the added protection of legal title. ${ }^{46}$

Kenyan property TDRMs take place in a plural environment where both informal and formal mechanisms work in tandem. ${ }^{47}$ Section I.A.1. herein provides an overview of the

41 See id. at 271; John Bruce, Kenya Land Policy: Analysis and Recommendations, at ix-x, 7-8 (May 2009); Karuti Kanyinga, The Legacy of the White Highlands: Land Rights, Ethnicity and the Post-2007 Election Violence in Kenya, 27 J. ConTEMP. Afr. Stud. 325, 328 (2009) (noting much of the high potential land was allocated to white settlers).

42 John Mutakha Kangu, Constitutional Law of Kenya on Devolution 82 (2015) (“"T] he transfer of land from the white settlers was also mismanaged as the greater part of the land was allocated to political elites."); Sessional Paper No. 3 of 2009 on National Land Policy para. 37 (Kenya); Lynet Igadwah, Few Kenyans Take Action Against Land Grabbing New Study Shows, Bus. DAILY (Feb. 25, 2016), http://www.businessdailyafrica. com/Few-Kenyans-take-action-against-land-grabbing/539546-3091760-109ss3r/index.html [https://perma. cc/9D5S-WSJA].

43 Int'1 Women's Human Rights Clinic, Women's Land and Property Rights in Kenya-Moving Forward into a New Era of Equality: A Human Rights Report and Proposed Legislation, 40 Geo. J. InT'L L. 1, 54 (2009).

44 Sessional Paper No. 3 of 2009 on National Land Policy para. 37 (Kenya).

45 Constitution art. 60(1)(g) (2010) (Kenya) (noting a principle of land management in Kenya is the "encouragement of communities to settle land disputes through recognised local community initiatives consistent with this Constitution"); Constitution sched. 5 (2010) (Kenya) (declaring the state had five years to develop a Community Land Act); Wiley, supra note 23 (stating that the Community Land Act was passed a mere ten days before the deadline).

46 See generally Community Land Act, No. 27 (2016) Kenya Gazette Supplement No. 148.

47 See Henrysson \& Joireman, supra note 5, at 40; Athena D. Mutua, Gender Equality and Women's Solidarity Across Religious, Ethnic, and Class Differences in the Kenyan Constitutional Review Process, 13 
constitutional framework. Section I.A.2. focuses on community land dispute resolution in legislation. Finally, Section I.A.3. describes customary dispute resolution processes. The confluence of these three areas of law is important to understanding the formalization of discriminatory practices.

\section{Land Institutions Under the 2010 Constitution}

The 2010 Constitution is, in the words of the Chief Justice, a "transformative constitution." ${ }^{" 48}$ It created a more equitable community land system through developments intended to stop land expropriations by previous governments. ${ }^{49}$ It defined the lands' caretakers, devolved national powers to the new county governments, and incorporated TDRMs.

First, the Constitution multiplied the number of caretakers. The Constitution mandated the creation of the National Land Commission to ensure independent decisions on land matters. ${ }^{50}$ At the same time, however, the government left the Ministry of Lands and Physical Planning intact, which created a tension between the mandates of the Commission and the Ministry. ${ }^{51}$ The National Land Commission is an independent commission with the power "to initiate investigations, on its own initiative or on a complaint, into present or historical land injustices, and recommend appropriate redress." ${ }^{52}$ Under the Land Act, the guiding principles of the National Land Commission include ensuring "equitable access to land," encouraging land TDRMs, and promoting the participation of the people..$^{53}$ The Ministry of Lands and Physical Planning, on the other hand, is a holdover from the

WM. \& MARY J. WoMEN \& L. 1, 15 (2006); Nyamu, supra note 14, at 23.

48 Yash Pal Ghai, The Law Aims to Give Every Kenyan Sense of Belonging, StAR (Jul. 30, 2016), http:// www.the-star.co.ke/news/2016/07/30/the-law-aims-to-give-every-kenyan-sense-of-belonging_c1394037 [https://perma.cc/A8XB-EPM6].

49 Constitution art. 61(1) (2010) (Kenya) ("All land in Kenya belongs to the people of Kenya collectively as a nation, as communities and as individuals.").

$50 \quad$ See id. art. 67.

51 Boone et al., supra note 22, at 10 ("The Land Laws (Amendment) Bill 2015 . . . transferred control over the land information systems back to the [Ministry of Land]").

52 Constitution art. 67 (2010) (Kenya).

$53 I d$. at art. 60. 
pre-2010 Constitution, and is directly under the power of the President. ${ }^{54}$ The National Land Commission Act allows the Ministry to remain in place for as long as the county governments are still being operationalized.$^{55}$ However, staff, assets, and responsibilities were meant to transfer to the independent National Land Commission. ${ }^{56}$ The result now is that both exist concurrently, there is significant overlap, and "neither the Ministry nor the [National Land Commission] is in a position to perform its tasks in isolation." ${ }^{57}$

Second, the new Constitution devolved some of the centralized national government's powers to the new county governments. ${ }^{58}$ Land was separated into three different categories: public, ${ }^{59}$ community, ${ }^{60}$ and private land ${ }^{61}$ County governments now hold community land in trust until a group decides to convert the "ancestral lands" into community-owned land through the Community Land Act. ${ }^{62}$ The Constitution grants decision-making about unregistered community land to the counties. This creates another layer of confusion because counties also have land officials whose job it has become to help solve community

54 Constitution art. 16 (1963, as amended in 2008) (Kenya) (stating the President may establish ministries and appoint ministers); National Land Commission Act (2015) Cap. 5D § 31(5) (stating that the staff of the Ministry of Lands and Physical Planning will continue its normal functions until the Commission or County Government have staff).

55 National Land Commission Act (2015) Cap. 5D §§ 30-32.

$56 \quad I d$

57 National Land Commission v. Attorney-General (2014) S.C.K. Advisory Opinion No. 2, para. 231.

58 Constitution art. 21, Ch. 11, arts. 176-185 (2010) (Kenya); Kangu, supra note 42, at 10 (noting devolution in Kenya is "a system of multilevel government under which the Constitution creates two distinct and interdependent levels of government - the national and county — that are required to conduct their mutual relations in [a] consultative and cooperative manner").

59 Constitution art. 62 (2010) (Kenya).

$60 I d$. art. 63 (community land is owned by a group of individuals who create "communities identified on the basis of ethnicity, culture or similar community of interest").

$61 I d$. art. 64 (private land is owned by individuals).

62 Constitution art. 63(3) (2010) (Kenya) ("Any unregistered community land shall be held in trust by county governments on behalf of the communities for which it is held."). The regulation of community land is done through the Community Land Act. Community Land Act, No. 27 (2016) KenYa Gazette Supplement No. $148 \S 6$. This act was passed in 2016; therefore, there is still much land that needs to be converted. The Supreme Court of Kenya has specifically held that "[t]he Commission has no special claim to the remit of administering or managing community land." National Land Commission v. Attorney-General (2014) S.C.K. Advisory Opinion No. 2, para. 226 (Kenya); National Land Commission Act (2015) Cap. 5D § 5(2)(e). 
land disputes. ${ }^{63}$ Presently, the Ministry of Lands and Physical Planning, the National Land Commissions, and the County Governments all have legal authority over land disputes.

Finally, the Constitution introduced a fourth player, TDRMs, and further complicated the matter. Article 60 of the Constitution mandates that land administration is "used and managed in a manner that is equitable," ${ }^{64}$ for the: "(f) elimination of gender discrimination in law, customs and practices related to land and property in land; and $(\mathrm{g})$ encouragement of communities to settle land disputes through recognised local community initiatives consistent with this Constitution." ${ }^{65}$ The Constitution bolstered this mandate: it states that "no more than two-thirds of the members of elective or appointive bodies shall be of the same gender" ${ }^{66}$ and gave the judiciary power to recognize "traditional dispute resolution mechanisms. ${ }^{.67}$ While the elimination of gender discrimination and community dispute resolution can be harmonious theoretically, the current TDRMs create a particular tension. The traditional institutions favor male elders as decision-makers, while non-discrimination calls for the participation of all community members. ${ }^{68}$ This final step results in four different institutions that can handle land disputes, the last of which is in tension with itself.

\section{The Introduction of Critical Community Land Legislation}

Community land dispute resolution is governed by many pieces of legislation that were changed after the 2010 Constitution. In 2012, the Land Adjudication Act was updated $^{69}$ and three new pieces of land legislation were promulgated that attempted to replace and consolidate older legislation: the National Land Commission Act, ${ }^{70}$ the Land Registration Act, ${ }^{71}$ and the Land Act. ${ }^{72}$ Finally, the Community Land Act of 2016 was

63 See infra note 80 and accompanying text.

64 Constitution art. 60(1) (2010) (Kenya); see also id. art. 47 (stating land administration must be "expeditious, efficient, lawful, reasonable and procedurally fair").

$65 I d . \operatorname{art.} 60(1)(\mathrm{f})-(\mathrm{g})$.

$66 I d$. art. 27(8).

67 Id. art. $159(2)(\mathrm{c})$.

68 For a description of why TDRMs involve only male elders, see infra Section I.A.3.

69 Land Adjudication Act (2016) Cap. 284 § 4.

70 National Land Commission Act (2015) Cap. 5D § 5 (establishing the National Land Commission).

71 Land Registration Act (2016) Cap. 300 (revising and reformulating the Registered Lands Act).

72 Land Act (2016) Cap. $280 \S 4$ (stating the purpose of the Act is "to revise, consolidate and rationalize 
passed to coordinate the laws that govern the adjudication, registration and administration of community land. ${ }^{73}$ In the end, three stages of community land emerge, each of which the new laws govern: ${ }^{74}(1)$ when the land is held in trust for communities ${ }^{75}(2)$ in the land adjudication and registration process ${ }^{76}$ and (3) in settling community land disputes after registration. ${ }^{77}$

Before community land is adjudicated, the county government holds it in trust for the community. ${ }^{78}$ The county government's administrative branch has a series of County Executive Commissioners ("CECs"): these are individuals, similar to ministers at the national level, with subject matter jurisdiction to help the Governor fulfill his or her function. ${ }^{79}$ One such position covers the administration and management of community

land laws").

73 Community Land Act, No. 27 (2016) Kenya Gazette Supplement No. 148.

"[C]ommunity" means a consciously distinct and organized group of users of community land who are citizens of Kenya and share any of the following attributes-

(a) common ancestry;

(b) similar culture or unique mode of livelihood;

(c) socio-economic or other similar common interest;

(d) geographical space;

(e) ecological space; or

(f) ethnicity.

Id. at $\S 2$.

74 This Note does not delve into the topic of land that is converted from the Land (Group Representatives) Act in accordance with $\S 47$ of the Community Land Act or other community ownership laws. For more information, see Community Land Act, No. 27 (2016) Kenya Gazette Supplement No. $148 § 47$.

75 This is the point when the land is neither adjudicated nor registered. Each community knows the boundaries of its land, although such boundaries are often a contested point between communities.

76 Land adjudication is the process by which the state determines and maps the boundaries of the land. INST. of Surveyors of Kenya, Guidebook on Procedures and Processes of Land Administration in Kenya 5 https:// www.academia.edu/18433350/GUIDEBOOK_ON_PROCEDURES_AND_PROCESSES_OF_LAND_ ADMINISTRATIONJ_IN_KENYA[https://perma.cc/7CJL-RMSZ].

77 Registration is the final stage when title deeds are handed to the community. Id.

78 What a trust means now is open to interpretation under the Community Land Act, which repealed the former Trust Land Act. Constitution art. 63(3) (2010) (Kenya); Community Land Act, No. 27 (2016) KenYA Gazette Supplement No. 148 § 6(1).

79 Constitution art. 179 (2010) (Kenya) (authorizing the creation of the County Executive Committees); Id. art. 183 ("A county executive committee shall . . perform any other functions conferred on it by this Constitution or national legislation."). 
land.$^{80}$ The CECs then have a staff, such as directors, that help with specific subtopic areas, like traditional dispute resolution processes. ${ }^{81}$

The Community Land Act of 2016 now governs disputes over preliminary community land adjudication and registration. The Act seeks to legitimize community land holdings, grant communities greater power over their land, and protect the land from illegal expropriation. ${ }^{82}$ The Cabinet Secretary of the Ministry of Lands and Physical Planning has until the end of 2019 to develop "a comprehensive adjudication programme" in consultation with the county governments. ${ }^{83}$ The program is subject to the Land Adjudication $\mathrm{Act}^{84}$ and the Land Registration Act. ${ }^{85}$ Therefore, these acts can begin to define the possible contours of the future program.

The Land Adjudication Act is the first step of the process to change customary land (untitled land) to formal land (titled land). ${ }^{86}$ The Ministry of Lands and Physical Planning appoints an adjudication officer to oversee the entire procedure, then this officer appoints demarcation, survey and recording officers. ${ }^{87}$ The District Commissioner $^{88}$ establishes

80 Land Laws (Amendment) Act, No. 28 (2016) Kenya Gazette Supplement No. 149 §§ 46(a)(1), 152D (implying that for each county there is a County Executive Committee member in charge of land matters).

$81 I d . \S 36$ (“)(2) In the performance of its functions, a county executive committee shall have power to determine its own programme of activities and every member of the committee shall observe integrity and disclosure of interest in any matter before the committee."); see also Boone et al., supra note 22, at 28 (showing that in practice CECs are involved in land disputes).

82 Community land, in particular, has a long history of land-grabbing attempts by local authorities. See generally Eric O’Brien, Kenyan Land Alliance, Irregular and Illegal Land Acquisition by Kenya's Elites (2011), http://www.kenyalandalliance.or.ke/wp-content/uploads/2015/03/KLA-commercial-pressure.pdf [https://perma.cc/94YY-6W35] (detailing the history and trends of illegal and irregular land-grabbing).

83 Community Land Act, No. 27 (2016) Kenya Gazette Supplement No. 148 §§ 8, 46(6); Wiley, supra note 23 ("Ensuring that an adjudication programme is launched — and implemented - within three years is a helpful, if unduly ambitious, obligation to lay at the Cabinet Secretary's door.").

84 Community Land Act, No. 27 (2016) Kenya Gazette Supplement No. 148 § 8.

85 See id. § 11.

86 Inst. of Surveyors of Kenya, supra note 76, at 4; see generally Smokin Wanjala, Land LaW AND Disputes IN KenYa (1990) (giving an analysis of the Land Adjudication Act before the 2010 Constitution).

87 Land Adjudication Act (2016) Cap. $284 \S 4$.

88 The District Commissioner is now known as the Deputy County Commissioner. The District Commissioner was an administrative officer of the national government under the 1969 Constitution. The 
a Land Adjudication Committee of no less than ten community members, ${ }^{89}$ and the adjudication officer appoints a non-voting executive officer to oversee the Committee. ${ }^{90}$ The landowners describe the boundaries of their land to the officers and if there is a dispute, the officers attempt to reach a resolution. If the officers cannot, then they hand the matter over to community members in the Land Adjudication Committee. ${ }^{91}$

The Land Registration Act covers disputes that arise during the registration of land. Under Section 19 of the Land Registration Act of 2012, boundary disputes are reported to the land registrar for hearing and determination..$^{92}$ Appeals against these determinations can "be made to the high court, land and environment court section." ${ }^{33}$ In practice, community members and the government often do not have the money to use formal methods. ${ }^{94}$ Therefore, the community attempts to resolve boundary disputes through TDRMs and the elders before bringing matters to the land registrar. ${ }^{95}$

Finally, the Community Land Act governs dispute resolution mechanisms after community land is titled. The Act requires that avenues of alternative dispute resolution be exhausted before the matter is appealed to a court. ${ }^{96}$ Even if the matter is brought before a formal court, these courts must apply the customary law of the community to

National Government Co-ordination Act effectively transferred most of the administrative officers to the new constitutional framework, however several position titles and functions were changed to reflect the principles of devolution. Some of these changed names have not yet been updated in the land laws. National Government Co-ordination Act No. 1 (2013) KenYa Gazette Supplement No. $115 \S$ 15(2)(b).

89 Land Adjudication Act (2016) Cap. $284 \S 6$.

$90 \quad I d$.

91 Inst. of SuRveyors of KenYA, supra note 76, at 4-5; see also Land Adjudication Act (2016) Cap. 284 §§ 15,19 (describing that it is a duty of these officers to hand the matter over to the land committee if they cannot solve the problem).

92 Land Registration Act (2016) Cap. 300 § 19.

93 Inst. of SuRveyors of Kenya, supra note 76, at 26-27 (stating the system of appeals for land decisions).

94 See Henrysson \& Joireman, supra note 5, at 46 (noting that elders often fill the gaps left by insufficient formal institutions).

95 Id.

96 Community Land Act, No. 27 (2016) Kenya Gazette Supplement No. 148 § 39 ("Where a dispute or conflict relating to community land arises, the registered community shall give priority to alternative methods of dispute resolution."); see also id. $\S 42$ ("Where all efforts of resolving a dispute under this Act fail, a party to the dispute may refer the matter to court."). 
resolve disputes over community land.$^{97}$ The Community Land Management Committee is the main alternative dispute resolution mechanism used, and it is comprised of seven to fifteen community members that handle routine disputes. ${ }^{98}$ As seen in Section I.A.3., this formal dispute resolution mechanism is quite similar to informal TDRMs. ${ }^{99}$ For instance, the Community Assembly consists of community members that vote for the Committee members, ${ }^{100}$ and the Committee cannot make any major changes to land resolution mechanisms without a majority vote of the Assembly. ${ }^{101}$ Finally, the Committee has many of the same functions as a council of elders, and the membership of the two bodies likely overlaps. ${ }^{102}$ These functions include the "development of community land use plans," and the promotion of "co-operation and participation among community members." 103

$97 I d . \S 39$ (" $[\mathrm{A}]$ court or any other dispute resolution body shall apply the customary law prevailing in the area of jurisdiction of the parties to a dispute or binding on the parties to a dispute in settlement of community land disputes so far as it is not repugnant to justice and morality and inconsistent to the Constitution.").

$98 \quad I d . \S 15$.

99 See discussion infra Section I.A.3.

100 Community Land Act, No. 27 (2016) Kenya Gazette Supplement No. 148 § 15.

101 Id. (mandating that decisions "to dispose of or otherwise alienate community land" need a two-thirds vote of "at least two thirds of the registered adult members of the community," while other decisions require a simple majority of those present).

102

(4) The functions of the community land management committee shall be to-

(a) have responsibility over the running of the day to day functions of the community;

(b) manage and administer registered community land on behalf of the respective community;

(c) coordinate the development of community land use plans in collaboration with the relevant authorities;

(d) promote the co-operation and participation among community members in dealing with matters pertaining to the respective registered community land; and

(e) prescribe rules and regulations, to be ratified by the community assembly, to govern the operations of the community.

Id.

103 See id. § 15(4) (detailing the participation of the community in matters pertaining to the land); Thom \& Martin, supra note 35, at 22 (explaining that Elders determined the allocation of land to individuals for cultivation, and the areas for pastures or fallowing); Karol C. Boudreaux, In One Kenyan Town, It's No Longer Just 'Old Wise Men', FrontLines (Sept. 19, 2016), https://www.usaid.gov/news-information/frontlines/ new-players-and-graduation/one-kenyan-town-it's-no-longer-just-'old-wise [https://perma.cc/UK49-WJBE] ("Elders traditionally hold the authority to decide disputes that bind both men and women in Kenya's villages."). 


\section{Traditional Dispute Resolution Mechanisms in Kenya}

TDRMs are the first and most important step in rural land dispute resolution and people can be angered and the legitimacy of a case undermined if the disputants do not turn to TDRMs first. ${ }^{104}$ In rural Kenya, the elders are the first to make decisions regarding land. ${ }^{105}$ The elders meet in a baraza (meeting) as a council of elders, often in conjunction with the chiefs ${ }^{106}$ who help to make and enforce decisions. ${ }^{107}$ Elders are almost all male and above middle age. ${ }^{108}$ In fact, gender, age, and status are the main determinants of leadership; ${ }^{109}$ this means that male elders traditionally exercise authority over the women who are not typically part of community land decision-making. ${ }^{110}$ Recently, however, there have been more women elders. ${ }^{111}$

Elders solve many types of disputes, but are crucial to land disputes because they are the keepers of memory; they remember the boundaries of the land based on markers such

104 See Vivian Jebet, Elders Dismiss Attempt by Parliamentary Committee to Resolve Land Disputes, DAILY NAtion (Feb. 16, 2016) http://www.nation.co.ke/counties/resolve-land-disputes/1107872-3079084-1338kjrz/ index.html [https://perma.cc/8ELH-6KPM] ("Mr Gonjobe however stated that the aggrieved group should have sought redress through local mechanisms including County Assembly, County Land Management Board and local council of elders.”).

105 See Henrysson \& Joireman, supra note 5, at 47; see also Elfversson, supra note 38, at 473-78 (referring specifically to the Kalenjin groups); PKALYA eT AL., supra note 5, at iv (referring specifically to the Kalenjin groups).

106 Elfversson, supra note 38, at 474 ("Chiefs collaborate with village elders in day-to-day local governance."); Juma, supra note 13, at 505; Mumma, supra note 30, at 4 (describing “community based 'courts' or arbitration barazas").

107 Int'1 Women's Human Rights Clinic, supra note 43, at 56 (“Assistant Chief Jackson Kirigia from the Meru area, [stated] local government officials also apply customary law when they are unfamiliar with the written laws: '[b]ecause [we] do not have the statutes or written laws, we usually invoke custom because that is what we know."').

108 See Elfversson, supra note 38, at 474 ("Authority within the community is tied to gender, age and status, with male elders traditionally exercising authority over the younger men and women who are not allowed to take part in community decision-making.").

109 Kalenjin elders are picked from the community because they are loyal, frank, kind, brave, self-sacrificing, moderate, and generous. They also promote unity, preserve balance and orderliness; they honored their own elders, and have been law abiding community members. See FisH \& FisH, supra note 8, at 262-63.

110 See Elfversson, supra note 38, at 474.

111 On my own trip to Kerio Valley, there were always mentions of an increased number of women elders, but I never had the pleasure of meeting one. 
as stones. ${ }^{112}$ TDRMs in land disputes therefore usually involve consensus building amongst the elders as to what exactly happened in the dispute, the nature of the boundaries and a decision about the remedy. ${ }^{113}$ The elders form a customary court or council with "broad and flexible powers to interpret evidence, impose judgments, and manage the process of reconciliation." "114 The remedy usually promotes "a sense of unity, shared involvement and responsibility, and dialogue among groups otherwise in conflict." 115 If the elders should fail to come to a decision, they can refer the dispute to a number of different bodies including older elders or formal mechanisms such as courts or national officials. ${ }^{116}$

While other forms of dispute resolution mechanisms, such as mediation, could work in the region, the form of TDRM described above has a specific and meaningful existence in people's lives. ${ }^{117}$ It is a trusted process that involves local community members. Other forms of dispute resolution, such as the land registrar and courts, are viewed as both inaccessible and expensive. ${ }^{118}$

112 Fred Kibor \& Edwin Cheserek, Oil Prospects Fuel Disputes Between Elgeyo Marakwet Clans, StANDARD Digital (Sept. 28, 2013), http://www.standardmedia.co.ke/lifestyle/article/2000094421/oil-prospectsfuel-disputes-between-elgeyo-marakwet-clans/?pageNo=2 [https://perma.cc/YB24-KQ3Z]; P. Favor, Boundary Harmonisation Meeting in Turkana Country, KenYa Land Alliance (Aug. 31, 2016), http://www. kenyalandalliance.or.ke/boundary-harmonisation-turkana-country/ [https://perma.cc/KAB2-8HV8].

113 See Pkalya et AL., supra note 5, at 4; see also Laurence Juma, Normative and Institutional Approaches to the Protection of Property Rights of IDPs in Kenya's Rift Valley Province, 20 Afr. J. Int'L \& Comp. L. 251, 259 (2012).

114 PKaLYA ET AL., supra note 5, at 4-5 (noting that elders listen to both sides and let grievances be aired, visit the location of the dispute, and talk with community members to understand the issue); Ezer, supra note 30, at 69-70 (noting that court interpretations of informal law "differs sharply" from community interpretations and does not have the same level of flexibility).

115 PKalya et Al., supra note 5, at 4; see also Kariuki, supra note 17, at 15 (explaining that the purpose of the elders' dispute resolution processes is to create "social cohesion, harmony, openness/transparency, participation, peaceful co-existence, respect, tolerance and humility").

116 See Henrysson \& Joireman, supra note 5, at 52.

117 See Jebet, supra note 104 ("Mr Gonjobe however stated that the aggrieved group should have sought redress through local mechanisms including County Assembly, County Land Management Board and local council of elders.").

118 Henrysson \& Joireman, supra note 5, at 40. 


\section{B. Institutionalist Theory}

The second co-dependent purpose of this Note is to shift the scholarly lens used to analyze changes in Kenya. ${ }^{119}$ Kenya is in a moment of institutional flux: the 2010 Constitution superimposed a number of new institutions on the old that were, and still are, solidifying their place in the government. In doing so, the Constitution radically changed the law, which now requires new interpretation and implementation. One such area of flux that affects many Kenyans, is the new laws that formalize TDRMs in community land disputes. The way in which these laws and new institutions are analyzed, interpreted, and described will have an impact on the implementation of TDRMs in Kenya. Institutionalism is a theory that has greatly influenced the field of law and development and is often used to interpret both the changes in institutions and the effects that they have on outcomes. ${ }^{120} \mathrm{As}$ a result, this theory has significantly affected the way legal scholars and practitioners interpret and create solutions for complex plural legal systems like that of Kenya. ${ }^{121}$ This Section will address two widely accepted characteristics of institutions: ${ }^{122}$ path dependency ${ }^{123}$ and

119 See De Soto, supra note 16, at 216 (arguing that certain formal property rights can ensure that the economic potential of developing countries is harnessed); NoRTH, supra note 14, at 9 (describing third world countries as having a "reverse set of incentives," where opportunities are redistributive and monopolistic, leading organizations that develop within this framework to have negative impacts on productivity).

120 Institutions are the "elementary rules, principle, or practice" of societies that constrain actions. JAMES Mahoney \& Kathleen Thelen, Explaining Institutional Change: Ambiguity, Agency, and Power 4 (2010); see also NoRTH, supra note 14, at 110 ("Third World countries are poor because the institutional constraints define a set of payoffs to political/economic activity that do not encourage productive activity."); Deakin et al., supra note 15, at 22 ("North ... stressed the role of law in general . . . in underpinning economic development and growth."); see generally Oona A. Hathaway, Path Dependence in the Law, 86 Iowa L. Rev. 601 (2001) (explaining law and path dependency); Paul A. David, Clio and the Economics of QWERTY, 75 AM. Econ. Rev. 332 (1985) (detailing science and path dependency); Douglass C. North et al., Violence and the Rise of OpenAccess Orders, 20 J. Democracy 55 (2009) (describing organizations and path dependency); Paul Pierson, Increasing Returns, Path Dependence, and the Study of Politics, 94 Am. Pol. Scr. Rev. 251 (2000) (explaining politics and path dependency).

\section{See supra note 16.}

122 Institutions also require some sort of enforcement mechanism. See generally Gillian Hadfield \& Barry R. Weingast, What is Law? A Coordination Model of the Characteristics of Legal Order, 4 J. Legal Analysis 471 (2012) (characterizing law as enforceable without State power). Contra Geoffrey M. Hodgson, On the Institutional Foundations of Law, 43 J. ECON. Issues 143 (2009) (characterizing law as requiring State enforcement).

123 See Pierson, supra note 120, at 251; Ruth Berins Collier \& DaVid Collier, Shaping the Political Arena 27 (1991); NoRTh, supra note 14, at 7; David, supra note 120, at 332 (noting economics has an "essentially historical" nature in which "one damn thing follows another."). 
the dichotomy between formal and informal institutions. ${ }^{124}$

\section{Path Dependent Institutions}

Institutions are comprised of rules and norms that create collective expectations for the future, and are, therefore, relatively stable. ${ }^{125}$ The first key characteristic of institutional theory is path dependency. Path dependency is the theory that small decisions start growth patterns in institutions that are difficult to change. ${ }^{126}$ With enough decisions made, the institution will "lock-in" to a certain pattern of behavior that is difficult or impossible to change. ${ }^{127}$ This theory offers an important interpretation of the current property TDRMs in Kenya: existing institutions can work to empower certain actors (i.e. the elders) who can continue to use these powers to affect institutional change, restrict access to social spaces, and influence the making and implementation of law that determines the institutional paths. ${ }^{128}$ One useful aspect of path dependency theory is its power to understand the paths these institutions will follow; but in a context like Kenya's, with many dispute resolution mechanisms, path dependencies become more difficult to predict.

\section{Plural Legal Context: Formal and Informal Law}

Scholars often use the terms "informal" and "formal" to describe plural legal contexts. ${ }^{129}$

124 "Informal" institutions are norms - such as putting a hand to the heart and swearing to invoke trustworthiness, while "formal" arrangements are usually characterized as laws - such as those to register land. NORTH, supra note 14, at 4.

$125 I d$. at 3 (describing institutions as immutable and deterministic).

126 Path dependency is the idea that once set on a path they continue to grow in that direction. See MAHONEY \& Thelen, supra note 120, at 4. Underneath these definitions is the idea that "[if] we want to know why a rule of law has taken its particular shape, and more or less if we want to know why it exists at all, we go to tradition." Oliver Wendell Holmes, Jr., The Path of the Law, in Collected Legal Papers 167, 186 (1920) (emphasis removed). Path dependency, however, is also more than a simple "history matter." Scott E. Page, Path Dependence, 1 Q.J. PoL. SCI. 87, 87 (2006).

127 James Mahoney, Path Dependence in Historical Sociology, 29 THEory \& Soc'y 507, 511 (2000); see also Page, supra note 126, at 88 (noting path dependency has four components: "increasing returns, selfreinforcement, positive feedbacks, and lock-in").

128 Deakin et al., supra note 15, at 7 (stating that legal institutionalism focuses on law as a mechanism of social power and "constitutive of social relations," shaping who has access to resources).

129 See generally North, supra note 14. Contra Winifred Kamau, Law, Pluralism and the Family in Kenya, 23 INT'L J.L. PoL'Y \& FAM. 133, 134 (2009) (“[T]his [law/custom] bifurcation runs counter to the reality on the ground, as people's family lives in Africa constantly traverse the boundaries of legal systems."). 
"Informal" institutions are norms such as putting a hand to the heart and swearing to invoke trustworthiness, while "formal" arrangements are usually characterized as laws, such as those laws that govern the process of land registration. ${ }^{130}$ Formal and informal can be characterized in relation to each other in a number of different ways: as in intractable tension, as in a negotiated relationship, or as mutually dependent. ${ }^{131}$ These characterizations are important to understanding the relationships among TDRMs (informal institutions), the new Constitution and land legislation (formal institutions), and gender equality. In the first characterization, informal and formal institutions are in an intractable tension: one is good while the other is harmful. ${ }^{132}$ If only one set of institutions is eliminated or effectively managed then all the problems of a plural legal system will disappear. ${ }^{133}$ For example, under this theory, a solution to the problem of gender inequality would be to eliminate TDRMs. In a "negotiated" relationship there is a "conscious" continuous interaction between formal and informal law in which each affects the other. ${ }^{134}$ For instance, the two are in constantly interacting; therefore, formal laws can be pitted against the informal TDRMs (or vice versa) to improve the situation of women.

Finally, mutual dependence is the notion that formal and informal institutions cannot exist without each other. ${ }^{135}$ In this example, the two are so intertwined and involved that they have become inseparable; thus, any solution to gender inequality must involve changes to both the formal and informal institutions. While each of these theories could be applied to the current legal landscape, only the latter truly captures Kenya's thick institutional context with multiple forms of dispute resolution.

130 See North, supra note 14, at 4 (describing the two forms of constraints, "formal constraints—such as rules that human beings devise - and informal constraints — such as conventions and codes of behavior").

131 Formal and informal institutions are arguably not separable at all. See Celestine Nyamu-Musembi, supra note 8, at 258 ("The sphere of local norms and practices is best described as being in a relationship of semiautonomy with the larger social matrix of formal laws."); NoRTH, supra note 14, at 4.

132 This theory has two subparts known as the "women in development" approach and the "legal imposition" theory. Nyamu, supra note 14, at 24.

133 See discussion infra Section II.B.2.

134 Nyamu, supra note 14, at 26; see also Aldashev et al., supra note 29, at 798; discussion infra Section II.B.2.

135 See Deakin et al., supra note 15, at 21 ("Law embodies both private (spontaneous) and state (designed) elements, among its non-accidental properties"). 


\section{Formalization of Discrimination and a Failed Theory}

The new land laws in Kenya have entrenched discrimination by formalizing TDRMs. First, the legal framework incorporates TDRMs into the formal law of Kenya in a way that both reifies certain practices and preserves a certain flexibility. Second, the formalization of TDRMs entrenches existing practices that discriminate against women and is in tension with the social aspirations of the new Constitution. Section A describes how the new Kenyan laws legitimize, formalize, and incorporate TDRMs. Section B examines how this formalization entrenches discrimination against women in dispute resolution mechanisms. Section C applies path dependency and legal pluralism to the current laws, and argues that these theories cannot fully explain the institutional context in Kenya.

\section{A. Formalization of Kenyan Law Regarding Community Land Disputes}

The Constitution and subsequent legislation effectively formalized land TDRMs by incorporating them into Kenyan law. This change is more than a simple acknowledgement of informal institutions. ${ }^{136}$ The legislative changes incorporate TDRMs in a variety of manners that both enfold these mechanisms into Kenyan law and preserve diverse dispute resolution practices. ${ }^{137}$

This Note assumes that, according to institutional theory, formalization occurs when two conditions are met: (1) informal institutions are solidified or codified; ${ }^{138}$ and (2) the right to punish is removed from unauthorized individuals and becomes the "legitimized monopoly"

136 The change is also not the creation of "conflicting systems of normative rules[] in Africa . . that are arguably impediments to institutional, legal and economic development." Hodgson, supra note 122, at 155.

137 Esther Mwangi \& Stephan Dohrn, Securing Access to Drylands Resources for Multiple Users in Africa, 25 Land Use Pol'y 240, 243 (2008) (describing different innovative tenure systems in Africa and arguing in part that the formalization of custom can produce laws that are rigid and do not adapt to multiple contexts); Klaus Deininger, World Bank Policy Review, Land Policies for Growth and Poverty Reduction 53 (2003) (stating that "customary systems of land tenure have evolved over long periods of time in response to locationspecific conditions").

138 See Hodgson, supra note 122, at 149 ("In a complex legal system it would be absurd to suggest that most people follow a particular law principally because they acquire the habit or other disposition in line with that law."); see also William Seagle, The Quest for Law 69 (1941) (“[C]ustom had to be declared to be law by a judgement in order to receive the necessary étatistic stamp."); see generally Hodgson, supra note 122 (explaining the different theories on the transition from informal law to formal law and arguing that "law is irreducible to custom" and that there is an inherent difference between formal and informal law). Contra Hayek, supra note 14, at 72 (alleging that law "in the sense of enforced rules of conduct is undoubtedly coeval with society"). 
of the State. ${ }^{139}$ In Kenya, the incorporation of TDRMs into the Constitution codifies these informal institutions. Second, while the formalization process does not change elders and TDRMs into judges and courts or remove the right to punish to the judicial branch, the process does extend the legitimate right to punish to local authorities and incorporates the decision-making process into the corpus of formal law. ${ }^{140}$ For instance, TDRMs are authorized in the Constitution under Article 159, which recognizes judicial authority and the legal system. ${ }^{141}$ Furthermore, Article 159 places limits on TDRMs' power so that they are not inconsistent with the laws of the land, ${ }^{142}$ while leaving room for variation to accommodate the many cultures of Kenya. ${ }^{143}$ This formalization effectively grants dispute resolution powers to communities and codifies TDRMs by placing limits on their power. This process of formalization happens at each of the three stages of community land.

\section{Stage One: Formalization by the County Government}

The Community Land Act has three stages, each with different dispute resolution processes. ${ }^{144}$ The first exists while the county government holds the land in trust and before the community decides to register its land. ${ }^{145}$ Currently, the county governments' County Executive Commissioners ("CECs") of land and their staff are the best placed to oversee land disputes under the constitutional mandate. ${ }^{146}$ However, because of the sheer number of land

139 See Hodgson, supra note 122, at 149 (noting further, however, that the right to punish should be the monopoly of the judiciary).

140 See Deakin et al., supra note 15, at 21.

141 Constitution art. 159(2)(c) (2010) (Kenya) (“[T]raditional dispute resolution mechanisms shall be promoted.").

142 See id. art. 159 (“)(3) Traditional dispute resolution mechanisms shall not be used in a way that - (a) contravenes the Bill of Rights; $(b)$ is repugnant to justice and morality or results in outcomes that are repugnant to justice or morality; or $(c)$ is inconsistent with this Constitution or any written law.").

143 See Mumma, supra note 30, at 2 ("[C]ultural aspects that come into play on any issue . . vary from community to community. Even in a community they may vary from one family to another.").

144 See discussion supra Section I.A.2. (describing the three stages of community land development and management).

145 See National Land Commission Act (2015) Cap. 5D §§ 5, 18. Although, as noted in Section I.A.2., these boards are still new in some areas and not yet equipped to handle the sheer number of cases. Therefore, the community often still relies on informal dispute resolution mechanisms. Henrysson \& Joireman, supra note 5, at $50-52$.

146 See supra notes 79-80 and accompanying text. 
disputes in Kenya, ${ }^{147}$ the CECs will need to (and do) rely on TDRMs to resolve unregistered community land disputes. ${ }^{148}$ The CECs' reliance on TDRMs effectively extends the power to resolve disputes and decide remedies (or punishments) to community members while the Constitution continues to define the acceptable limits of these mechanisms.

\section{Stage Two: Formalization by the National Government}

The second stage is the adjudication and registration of community land borders. ${ }^{149}$ The Community Land Act states that the Ministry of Lands and Physical Planning has three years to come up with a program that can elaborate on the existing land laws. ${ }^{150}$ In the meantime, the process of boundary adjudication will likely follow the methods provided in the Land Adjudication Act. ${ }^{151}$ The District Commissioner chooses community members for the Land Adjudication Committees, while the adjudication officer selects the nonvoting executive officer. ${ }^{152}$ If the various Ministry officers are unable to resolve disputes, the matter is handed to these committees made up of local community members. ${ }^{153}$ The committees are formalized: they are both codified in the Land Adjudication Act and granted the power to make decisions regarding community land. This system not only incorporates community members (usually male elders) into formal dispute resolution mechanisms, but it also puts the committees into a formal hierarchy of decision-makers.

\section{Stage Three: Formalization through the Community Land Act}

The final stage of community land management is after the community land is registered. This is the newest formalization of land TDRMs in Kenya. The form of the land dispute committee is defined and codified in the Community Land Act and the power to make

147 According to a 2005 study of land conflicts in the central and western regions of Kenya, of the 899 households surveyed, "the sampled households are worried about future land conflicts on 9.3 percent of all parcels and have pending conflicts on 4.3 percent of their parcels." Takashi Yamano \& Klaus Deininger, Land Conflicts in Kenya 2 (Found. for Advanced Stud. on Int'l Dev., Discussion Paper No. 2005-12-002, 2005).

148 See supra notes 79-80 and accompanying text.

149 The land registrar is already recognized as a formal dispute resolution mechanism that involves only national officials; therefore, it will not receive further attention in this Note.

150 Community Land Act, No. 27 (2016) Kenya Gazette Supplement No. 148 §§ 8, 46(6).

$151 I d . \S 8(1)$ (stating that the adjudication program is subject to "any law relating to adjudication of titles").

152 Land Adjudication Act (2016) Cap. $284 \S 6$.

153 Id. $\S \S 15,19$. 
decisions is firmly placed in a Community Land Management Committee. ${ }^{154}$ Every member of the community is part of the Assembly, which elects the Community Land Management Committee to oversee the common land. ${ }^{155}$ These members are solely elected by those living on community land and are not appointed by officials. This structure functions much like a corporation ${ }^{156}$-all matters must first go to these Committees who propose rules that the Assembly ratifies, and the Committee cannot make any drastic changes (such as selling land) without an assembly vote. ${ }^{157}$ Furthermore, if a dispute is ever appealed to a formal court, informal laws are applied. ${ }^{158}$ This puts enormous power in the hands of the community — specifically the Committee — to decide matters and create the law of the land.

\section{B. Entrenching Discrimination}

Each stage described above has the potential to further entrench TDRMs that do not include women, youth, and other marginalized groups. This is because each incorporates informal institutional arrangements that favor male elders as decision-makers, especially in matters pertaining to land. ${ }^{159}$ While the Constitution contains many provisions that protect equal outcomes for women, equal participation in land dispute resolution processes is also crucial. Formalization is not simply the recognition of TDRMs; it also has the ability to entrench the disempowerment of more than half the Kenyan population because women are excluded. ${ }^{160}$ As stated in Section I.A.3., gender is a major determining factor for

154 Community Land Act, No. 27 (2016) Kenya Gazette Supplement No. 148 §§ 7, 15.

155 Id. $\S 15$.

156 See Hakijamil, Realizing Land Tenure Reforms in Kenya 14 (2014) http://www.hakijamii.com/wpcontent/uploads/2016/05/Final-Community-land-bill-booklet.pdf [https://perma.cc/R2X6-G782] (stating that the community is "registered as a legal corporate entity with a common seal and legal powers to sue and be sued, to enter into contracts, to acquire, purchase, hold, charge and dispose of property, and power to borrow money").

157 See Community Land Act, No. 27 (2016) Kenya Gazette Supplement No. 148 §§ 15, 42.

158 See id. $\$ 39$.

159 See discussion supra Section I.A.3. (describing the traditional decision makers in Kenya).

160 This is because youth — both male and female — are excluded from land dispute resolution mechanisms. See Nyamu-Musembi, supra note 131, at 264. In other types of group land management, such as group ranches, male elders' opinions are also favored over those of women and youth. See also Robert M. Kibugi, A Failed Land Use Legal and Policy Framework for the African Commons?, 24 J. Land Use \& EnvtL. L. 309, 324 (2009). 
participation in dispute resolution mechanisms: ${ }^{161}$ most women do not have full rights over land, let alone access to making decisions about land since it is predominately viewed as the domain of older men. ${ }^{162}$ In fact, women in rural areas have often never heard of the property laws or the procedures to protect property rights. ${ }^{163}$ Furthermore, informal laws govern a large portion of Kenyan land, ${ }^{164}$ and it is estimated that in 2006 only one percent of Kenyan women held sole title to land. ${ }^{165}$

\section{Discrimination in the Three Stages of Community Land}

Discrimination is becoming increasingly entrenched in all three stages of community land as Kenyan law has formalized each stage. In the first stage, while the ways counties will handle land disputes are still in flux, ${ }^{166}$ it is likely that the CECs will rely on the TDRMs in unregistered communities. ${ }^{167}$ Therefore, TDRMs will have the continued support of the counties. In the second stage, the Land Adjudication Committees may be subject to constitutional gender limits. ${ }^{168}$ Historically however, these committees are the domains of male elders: "the committees have no women and the average age of the members is at least fifty years." ${ }^{169}$ The explanation usually given is that old men know the history of the

161 See Henrysson \& Joireman, supra note 5, at 41 ("Customary law provides a system of rules for the allocation and adjudication of property rights. Typically, it is used as a tool through which traditional leaders (chiefs, elders, or headmen) can evaluate claims to property and resolve disputes regarding land.").

162 See id. at 43 ("[M]ost African women in customary tenure systems, have only secondary or use rights to their husband's land"); FIDA, Women's Land and Property Rights in KenYa 2-3 (2009) ("Women have traditionally been excluded from decision-making processes regarding land; men hold the vast majority of the land titles and the vast majority of the seats on land boards."); FIDA KenYA, supra note 17, at 4-5 (stating traditional adjudication mechanisms "were male dominated and that women often faced the challenge of lack of access to fair justice").

163 FIDA KenYa, supra note 17.

164 See Reem Gaafar, Women’s Land and Property Rights in Kenya (2014).

165 Kenya Land Alliance, Women Land \& Property Rights, http://www.kenyalandalliance.or.ke/womenland-property-right/ [https://perma.cc/MX2X-NZSL].

166 See supra note 24.

167 See supra notes 79-82 and accompanying text (describing the functions of the county executive committee under the Constitution).

168 See Constitution art. 27(8) (2010) (Kenya) (mandating the two-thirds gender rule, which is that no appointive position will be comprised of more than two-thirds of one gender).

169 Nyamu-Musembi, supra note 8, at 264; Karanja, supra note 7, at 121. 
land. ${ }^{170}$ In the final stage, while the Community Assembly may be made up of all members, the Community Land Management Committees are elected, and there is already heavy cultural bias toward electing male elders as decision-makers in all matters, especially land matters. ${ }^{171}$ Because this is not an appointive or elective position of the government, it is arguably not subject to the constitutional limits on gender participation in official bodies. ${ }^{172}$ Each stage, in effect, formalizes discriminatory dispute resolution practices.

The law does provide checks to the formalization of TDRMs. The Community Land Act states, "[e]very member of the community has the right to equal benefit from community land ... [and] [w] omen, men ... have the right to equal treatment in all dealing with community land." ${ }^{173}$ The Constitution states that TDRMs must be just and moral. ${ }^{174}$ Finally, the Bill of Rights creates the duty to address the needs of vulnerable groups, ${ }^{175}$ the equal protection and equal benefit of the law, ${ }^{176}$ the right to equal opportunities, ${ }^{177}$ and the

170 See Nyamu-Musembi, supra note 8, at 264 ("In practice, 'persons' has come to mean male elders . . . the explanation that I got for this practice is that old men are the ones who know the history of landholding in the area ...").

171 See supra notes 161-68 and accompanying text (showing how discrimination against women participating in adjudication is regular practice in Kenya).

172

(6) To give full effect to the realisation of the rights guaranteed under this Article, the State shall take legislative and other measures, including affirmative action programmes and policies designed to redress any disadvantage suffered by individuals or groups because of past discrimination ....

...

(8) In addition to the measures contemplated in clause (6), the State shall take legislative and other measures to implement the principle that not more than two-thirds of the members of elective or appointive bodies shall be of the same gender.

Constitution art. 27 (2010) (Kenya).

173 Community Land Act, No. 27 (2016) Kenya Gazette Supplement No. 148 § 30(1).

174 Constitution art. 159(3)(b) (2010) (Kenya).

175 Id. art. 21(3) ("All State organs and all public officers have the duty to address the needs of vulnerable groups within society, including women, older members of society, persons with disabilities, children, youth, members of minority or marginalised communities, and members of particular ethnic, religious or cultural communities.").

$176 I d$. art. 27(1) ("Every person is equal before the law and has the right to equal protection and equal benefit of the law.").

177 Id. art. 27(3). 
right to freedom of expression. ${ }^{178}$ While these rights do uphold equal benefit of the law, equal participation is less certain in formalized mechanisms. The current number of female landowners and the state of women's participation in land dispute resolution demonstrate that even the benefit is not truly reaching all people. It is easy to argue that there is no particular rule that holds women back from participation. It is also commonly argued that women do have the opportunity to participate, but do not take it up for cultural reasons. Yet in a system that formalizes cultural reasoning and institutions, it is even more important to ensure that women are part of the formalized land dispute resolution mechanisms that set the norms for the entire community and control vital assets such as land.

\section{Processes Affect Outcomes}

The formalization of male elders in positions of power is important because people who make decisions shape the outcomes. The informal, customary rules that disfavor women are much easier to change when those experiencing the discrimination have the power to affect the outcomes of TDRMs. Under Kenya's informal institutions women have "no rights to own land and only limited rights to access or use land." 179 Women often do not have the money to pay local dispute resolution bodies, let alone enough to bring their cases to formal courts for appeal where women's rights may be more likely to be enforced. ${ }^{180}$

Furthermore, most informal mechanisms are the domain of male elders or officials who follow customs that are "often based on discriminatory and degrading notions about women's inability to manage or own land." 181 Therefore, it is not surprising to see situations

$178 I d$. art. 33(1) ("Every person has the right to freedom of expression."); Id. art. 34(4)(c) (stating people have a right to the "fair opportunity for the presentation of divergent views and dissenting opinions.").

179 Int'1 Women's Human Rights Clinic, supra note 43, at 51.

180 Women are even less likely to be able to pay formal courts after they have paid multiple informal mechanisms. Henrysson \& Joireman, supra note 5, at 40 ("Rent-seeking ... [at] both the formal and informal adjudication processes, make the settling of land disputes prohibitively expensive.").

Finally, women are unable to effectively assert their rights to property because of gender bias in customary law and the lack of procedural safeguards for land disputes. Women are excluded from the decision-making process as men hold the vast majority of seats in institutions that adjudicate land rights. The decisions emanating from those bodies are often based on discriminatory and degrading notions about women's inability to manage or own land, some of which are enshrined in customary law. As a result, women are subjugated to the status of second-class citizens who must rely on men as the sources of their rights.

Int'1 Women's Human Rights Clinic, supra note 43, at 51. 
where women who go to local officials with pleas contrary to customary norms only make their situations worse because they attempted to stand against discrimination. ${ }^{182}$ However, organizations that work in Kenyan communities have shown that when women are included in TDRMs, results can change drastically for the better. When women are elected elders, domestic abuse and other forms of discrimination can be stopped because women's voices and concerns are heard and respected by female elders. ${ }^{183}$ Equal participation in the processes of adjudication can have a strong impact on outcomes.

The protections codified in the Constitution and the Community Land Act do not unambiguously protect women, because these safeguards do not promote women's place in TDRMs. ${ }^{184}$ In fact, the formalization of TDRMs with all male elders has the potential to further reify structural discrimination against women. While the Bill of Rights contains protections for gender-neutral outcomes, these are not active attempts to include women in TDRMs norm-creation processes. Therefore, there is a risk that traditional gendered roles will trump women's participation in these processes.

\section{Theoretical Issues}

So far, this Note has suggested that TDRM practices will always discriminate against women. Standard theories offered by institutionalists further corroborate that futures are path dependent and that informal institutions are inflexible. ${ }^{185}$ However, by focusing solely on immutable paths, it is easy to overlook structures that provide a space for change. ${ }^{186} \mathrm{It}$ is

182

Naimodu sought the help of the local elders. Elders traditionally hold the authority to decide disputes that bind both men and women in Kenya's villages. Naimodu hoped they would help intervene to stop her husband's beatings. But the elders, all men, sided with her husband. And bringing a case against him only led to more abuse when she returned home. Boudreaux, supra note 103.

183 See id. (stating that the male elders finally listened, and Naimodu's husband stopped beating her "when Naimodu and 10 other women in Ol Pusimoru, an area with a population of about 2,500, were formally elected as elders.").

184 For example, Article 27(3) of the Constitution states that "[w]omen and men have the right to equal treatment, including the right to equal opportunities in political, economic, cultural and social spheres." However equal opportunity does not take into account that traditional norms block women's access to TDRMs, and because these positions are not official positions, they are not necessarily subject to the two-thirds gender rule. Constitution art. 27 (2010) (Kenya).

185 See discussion supra Section I.B. (describing institutional theories).

186 See generally Nyamu, supra note 14 (arguing in part that formal and informal laws are in constant 
well known that cultures and customs are "not deterministic." 187 Both path dependency and certain characterizations of legal pluralism in institutionalism are inadequate to address or describe the current situation in Kenya. These theories provide static outlooks that focus on the consistency of Kenya's current property institutions and do not allow room for analyzing and promoting change.

\section{Detrimental Path Dependency}

North and others argue that institutions are path dependent, meaning that they will continue to develop and grow in the direction they are set. ${ }^{188}$ Kenya has experienced a number of changes over a very short amount time: a new Constitution, reformed land laws and most recently, the Community Land Act. Taken singularly each of the institutions described is arguably path dependent. For instance, the Land Adjudication Committees create a path that will determine the development of the new "adjudication programme" under the Community Land Act. ${ }^{189}$ Under a theory of functional path dependency, those who have traditionally held power - male elders - will continue to adjudicate matters under the new program, because they have already served a very functional and useful purpose in the Committee. ${ }^{190}$ Under a utilitarian theory of path dependency, change is unlikely, because the process of including more women in TDRMs will be more expensive than maintaining the status quo. ${ }^{191}$ In a "power" theory of path dependence, male elders will arguably work

conversation in Kenya and that theories that favor formal law or informal law are not capturing the true essence of Kenyan law).

187 See Nyamu-Musembi, supra note 131, at 269-71;

Laws of inheritance that appear to be reproducing a social situation from generation to generation may in fact be accommodating changes that are not acknowledged as such ... . The past may be formally invoked to legitimize the present; yet the actual practices may be only selectively perpetuated, and change may be accommodated under the cloak of ancestral custom.

Sally Falk Moore, Law as Process: An Anthropology Approach 243 (1978).

188 See NORTH, supra note 14, at 118.

189 Community Land Act, No. 27 (2016) Kenya Gazette Supplement No. 148 § 8.

190 Mahoney, supra note 127, at 519 (citing Robert K. Merton, Social Theory and Social Structure: Toward the Codification of Theory and Research 24 (1957)); Id. at 521 (defining a function as meaning "the notion of 'interdependence,' 'reciprocal relation,' or 'mutually dependent variations").

191 Id. at 516; NoRTH, supra note 14, at 99 (explaining how inefficient paths continue because the costs of change outweigh the benefits). 
hard to maintain their positions of power. ${ }^{192}$ Finally, the legitimacy of elders can be so ingrained in the social structure that change is unlikely. ${ }^{193}$

When these path dependent ideas are put together a certain type of thinking develops in which Kenya has a "reverse set of incentives." 194 This type of analysis can lead many to develop pessimistic policies about change when in reality the situation is much more complex than simple one-directional incentives. Kenya has introduced a new institutional framework that has formalized informal institutions. These legal changes establish a space where multiple path dependencies collide and create a situation of institutional fluidity. Path dependency as a tool alone cannot adequately describe and predict the mix and growth from the group of overlapping institutions. ${ }^{195}$

\section{Deficient Conception of Legal Pluralism}

There are several ways to describe the overlapping formal and informal institutions: as in intractable tension, as a negotiated relationship, or as mutually dependent. ${ }^{196}$ The first two theories describe a form of legal pluralism that while useful in other contexts does not adequately describe the current context in Kenya. The latter theory encapsulates the current intermixture of formal and informal institutions that create Kenya's unique institutionally fluid context.

The theory that informal and formal institutions are in intractable tension with one

192 See Mahoney, supra note 127, at 521; see generally Anthony Oberschall \& Eric M. Leifer, Efficiency and Social Institutions: Uses and Misuses of Economic Reasoning in Sociology, 12 Ann. Rev. 233 (1986) (explaining that certain institutional configurations benefit some individuals over others; therefore, those in power are likely to continue to support structures that benefit their interests).

193 See Mahoney, supra note 127, at 523; John Dowling \& Jeffrey Pfeffer, Organizational Legitimacy: Social Values and Organizational Behavior, 18 PACIFIC Soc. Rev. 122, 123 (1975) (stating that institutions are path dependent due to subjective norms of morality and belief: in order for an organization to continue, it must be relevant to its social context because it derives its legitimacy from the social structure).

194 NoRTH, supra note 14, at 9.

195 It is difficult to forge a single set of institutions even with a top-down governmental mandate and coercive force that sets a path clearly. Colonization offers a good example of the difficulties in making institutions converge. Just as colonization imposed a western property system on Kenyan institutions that did not lead to one set property system, so too will the confluence of multiple means of property dispute resolution not solidify in one set manner in Kenya. See, e.g., Sally Falk Moore, Treating Law as Knowledge, 26 L. \& Soc'Y Rev. 11 (1992).

196 See supra note 131 and accompanying text. 
another can be described in one of two ways: the "women in development" approach and the "legal imposition" theory. ${ }^{197}$ In the first, informal institutions, such as TDRMs, are responsible for the gender imbalance, and the formal institutions are good and gender neutral. ${ }^{198}$ In Kenya, formal institutions are legitimizing TDRM practices; they are part and parcel of the legitimization of discriminatory practices. Furthermore, TDRMs are not necessarily harmful, rather as described above, the manner in which they are employed can lead to increased discrimination or increased gender-neutral participation. ${ }^{199}$ In the opposite manner, the legal imposition theory romanticizes the role of informal laws (custom) in protecting women's rights and sees the current property system as a western imposition. ${ }^{200}$ As shown in Section II.B., TDRMs in many parts of Kenya do not include women; therefore, romanticizing informal institutions is also not the answer. ${ }^{201}$

In a negotiated relationship or "critical pragmatic" approach to legal pluralism, there is a "complex dynamic intersection of prevailing notions of local customs and national formal legal structures ... [which] remains conscious of the continuous interaction." ${ }^{202}$ Informal and formal institutions are in a contested dialogue affecting each other. The space between formal and informal law is one of contestation and influence that can result in alienation or in one set of institutions acting as a magnet to the other creating slow, incremental change. ${ }^{203}$ While this is a better characterization of the current situation in Kenya, it does

197 Nyamu, supra note 14, at 24.

198 Id. at 25 ("Kenya's constitution and laws do not discriminate against women. However, certain traditional practices inhibit women's equal access to and ownership of property."); see also CONFERENCE RePORT, FOURTH World Conference on Women (Sept. 4-15, 1995), at 5.

199 Elinor Ostrom, Developing a Method for Analyzing Institutional Change, in Assessing tHe EvoluTION and Impact of Alternative Institutional Structures 281, 282 (Sandra S. Batie \& Nicholas Mercuro eds., 2008) ("[R]esource users, who have relative autonomy to design their own rules for governing and managing common-pool resources, frequently achieve better outcomes than when experts do this for them.").

200 Nyamu, supra note 14, at 24.

201 Furthermore, while resource users often develop better outcomes informally, these are not necessarily the best outcomes. See Daniel Fitzpatrick, 'Best Practice'Options for the Legal Recognition of Customary Tenure, 36 Dev. \& Change 449, 472 (2005).

202 Nyamu, supra note 14, at 26.

203 Aldashev et al., supra note 29, at 798. The authors argue that when a problem arises a person has two options: the person can resort to the formal judges (representing formal law that is more favorable to them, for instance, laws that protect women's rights) or the person can resort to the informal judge (representing the social norms and customs, which may not contain the same protections for women). If the formal law is not too different from the customary law, the risk of appeal to the formal judge will push the informal judge to align 
not take into account that these institutions are closer than one might think. Actors may be shared between multiple institutions, creating a web of interactions that fluidly spans formal and informal spaces. ${ }^{204}$

Finally, mutual dependence is the notion that formal and informal institutions cannot exist without each other. ${ }^{205}$ This is the best characterization of the situation in Kenya. In a mutually dependent situation informal institutions have a higher body (like the State) that enforces the law, recognizes the hierarchy of the formal and informal institutions, and steps in to keep the system from self-destruction in the last instance. ${ }^{206}$ At the same time, the formal law's power is derived from its ability to graft onto informal institutions as a system of "shared social rules." ${ }^{207}$ In Kenya, the CECs, adjudication officers, and the national government enforce the law, often through the chiefs. Article 159 of the Constitution and Community Land Act Sections 39 and 42 recognize a clear hierarchy between formal and informal institutions. ${ }^{208}$ The ability to appeal to courts makes TDRMs extensions of the government that are preserved under formal law. ${ }^{209}$ Therefore, the new Constitution and community land laws are best described as mutually dependent.

\section{A New Framework}

Kenya is in a state of institutional fluidity where discriminatory practices are not yet solidified; however, this does not mean that discriminatory practices are not prevalent or relevant. What institutional fluidity does offer is three important contributions: path dependency and a clear formal/informal dichotomy are no longer all-inclusive institutionalist answers to development questions, change is both probable and encouraged, and solutions from both legal and social contexts are interconnected and have equal importance. Section III.A describes institutional fluidity as a new typology for understanding the institutionalism

informal law with the more favorable formal law causing positive institutional change. Id. at 801-03.

204 See discussion infra Section III.A.2.

205 See supra note 131 and accompanying text.

$206 I d$.

207 See Deakin et al., supra note 15, at 21.

208 Constitution art. 159 (2010) (Kenya); Community Land Act, No. 27 (2016) Kenya Gazette Supplement No. $148 \S \S 39,42$.

209 See Constitution art. 159 (2010) (Kenya); Community Land Act, No. 27 (2016) Kenya Gazette Supplement No. $148 \S \S 2,39,42$ (allowing referral to the Environmental and Land Court if the TDRM fails, however customary law applies in both of these judicial forums). 
in Kenya. Section III.B explains opportunities for change in Kenya's informal and formal institutions that can prevent discrimination and sustain flexible TDRMs.

\section{A. Kenya is in a Moment of Institutional Fluidity}

Institutional fluidity is the result of two separate factors that together create a space where new institutional contexts are primed for change: a confluence of forums and interconnecting actors. A confluence of forums is a situation where many different dispute resolution mechanisms that have separate path dependencies and structures are brought together in a new way. While traditionally, actors are associated with either the formal or informal spheres, interconnecting actors in an institutionally fluid space can cross-pollinate organizations and create situations that influence multiple forums. Together these factors create a system where structures collide and interconnect to create institutional fluidity. ${ }^{210}$

\section{Confluence of Forums}

Historically, the arc of property law and dispute resolution mechanisms in Kenya has disenfranchised women and youth. ${ }^{211}$ It is possible that formal and informal Kenyan institutions will continue to entrench or encourage discrimination because of path dependency. However, Kenya is in a unique position with a confluence of formal property adjudication mechanisms and TDRMs. ${ }^{212}$ There are, and have been, so many institutions in Kenya that there is an "ambiguity and inconsistency in ... understanding official dispute resolution channel[s]" and how they fit with TDRMs. ${ }^{213}$ For example, the Cabinet Secretary will develop a "comprehensive" method for adjudicating new community land. ${ }^{214}$ In practice, however, the council of elders and the Land Adjudication Committees already

210 For an interesting example of when a hybrid public/private system has developed in an arguably similar way, see Yingyi Qian, How Reform Worked in China, in In Search of Prosperity: Analytic Narratives on ECONOMIC GROwTH (Dani Rodrik ed., 2003) (describing the mixture of private and public institutions in China that created unprecedented growth).

211 See discussion supra Section I.A.3. (explaining the age and gender bias in choosing leaders who make decisions for the community); see also discussion supra Section II.A.2. (describing how the new laws in Kenya entrench this discriminatory practice in TDRMs).

212 For example, there can be significant overlap in the Community Land Management Boards, the County Executive Commissioners of land, the national government's land adjudication officers, the Land Adjudication Committees, and the elders.

213 Henrysson \& Joireman, supra note 5, at 52.

214 Community Land Act, No. 27 (2016) Kenya Gazette Supplement No. 148 §§ 8, 46(6). 
have institutional arrangements as well as an equal mandate in adjudication processes. ${ }^{215}$ This creates a situation where multiple means of resolving land disputes come together. ${ }^{216}$ The path dependencies of each institution collide to create a moment of institutional fluidity where dispute resolution mechanisms are a contested space that can be influenced and changed by the choices of its constituencies. The multitude of forums also creates a situation where Kenyan citizens can favor certain institutions over others to signal preferences and create change.

\section{Interconnecting Actors}

Kenya's formal and informal institutions are also mutually dependent. ${ }^{217}$ Part of the essence of mutual dependence is not only that formal institutions change informal institutions, ${ }^{218}$ but that informal institutions can radically change formal institutions. Land dispute resolution mechanisms share not only a common purpose limited by Article 159 and solidified by constitutional and legislative provisions, but also often share actors. ${ }^{219}$

215 Boudreaux, supra note 103 (stating that elders have the power to decide land disputes and that the population is bound to these decisions); Land Adjudication Act (2016) Cap. 284 § 6 (establishing the Land Adjudication Committees to decide land adjudication disputes if the officers fail to resolve them); Community Land Act, No. 27 (2016) Kenya Gazette Supplement No. $148 \S 15$ (establishing the Community Land Management Boards to help resolve disputes).

216 It is worth noting that sometimes the actors are on multiple committees-for instance, an elder on the (now-dissolved) County Land Management Boards. This happens because it makes sense to incorporate local land knowledge and respected individuals to boost the legitimacy of such boards and committees. Some scholars argue that the multiplicity of forums creates "forum shopping" situations, which may not adequately protect the property rights of disadvantaged groups. Ann Whitehead \& Dzodzi Tsikata, Policy Discourses on Women's Land Rights in Sub-Saharan Africa, 3 J. Agrarian ChAnge 67, 95-96 (2003). However, others argue that it is precisely this type of forum shopping that can create positive change. Aldashev et al., supra note 29, at $798,801-03$.

217 See also discussion supra Section II.B.2. (describing various interpretations of the interactions of informal and formal institutions). The success of institutional combinations of actors and institutional forms has also been noted in China's mixture of public/private corporations. Li-Wen Lin \& Curtis J. Milhaupt, We are the (National) Champions: Understanding the Mechanisms of State Capitalism in China, 65 Stan. L. Rev. 697 (2013).

218 See generally Aldashev et al., supra note 29 (arguing that formal law can be used as a magnet to pull informal institutions towards change).

219 See discussion supra Section I.A.1. (arguing that the recent legislative changes have formalized informal mechanisms of dispute resolution). 
Elders in Kenya often sit on land committees as well as on their own council of elders; ${ }^{220}$ therefore, both the new Kenyan law and the precepts of TDRMs influence these institutions.

\section{B. Movement Toward Change}

The problem of discrimination in Kenya's land dispute resolution mechanisms is both a social and legal one: the new laws formalize TDRMs and embed structural discrimination, however, the discrimination comes from the TDRMs. Therefore, solutions must encompass both the legal and social fields. Institutional fluidity in Kenya helps refine the possible legal and social solutions to the formalization of discrimination in community land dispute resolution. The confluence of forums demonstrates that solutions must be focused on creating cohesive change across forums. The interconnected nature of the actors in different mechanisms shows that solutions which focus on overlapping actors can significantly influence other institutions. The Supreme Court held that land institutions must be in a relationship of "mutual co-operation, co-ordination, and consultation." ${ }^{221}$ Each of the stages of community land has different institutions that have room for overlapping social and legal changes that can ensure women are included in land dispute resolution mechanisms.

\section{Dealing with Discrimination in Stage One: Land in Trust}

There are multiple opportunities for both legal and social change that can prevent discrimination. Under Article 63 of the Constitution, the county government holds unregistered community land in trust. ${ }^{222}$ County Executive Commissioners can be a useful point for eliminating discrimination because of their regulatory and administrative position. Appointee bodies within the government must not be more than two-thirds one gender. ${ }^{223}$ The Governors therefore can be a part of the solution by appointing women to CEC land positions, and CECs themselves can ensure that a significant portion of their staff handling land matters are women. This would set an example for other parts of the government

220 For example, an elder of an entire sub-county also sat on the now-dissolved County Land Management Board of Elgeyo Marakwet County. See also Nyamu-Musembi, supra note 131, at 264 (describing a Land Adjustment Committee as "hav[ing] no women and [with] the average age of the members [] at least fifty years.").

221 National Land Commission v. Attorney-General (2014) S.C.K. Advisory Opinion No. 2, paras. 253 (Kenya).

222 Constitution art. 63(3) (2010) (Kenya).

223 Id. art. 27(8). 
and TDRMs and start to break down the idea that women cannot be involved in decisions regarding land.

Different organizations in Kenya have shown that social change through informal institutions is both possible and successful. ${ }^{224}$ Elders are often eager for training and development, which provides an opening for human rights engagement. ${ }^{225}$ These trainings can be accomplished through the National Land Commission. The Constitution encourages land administration that both recognizes TDRMs and eliminates gender discrimination. ${ }^{226}$ The Commission is mandated in Section 5 to "develop and encourage alternative dispute resolution mechanisms in land dispute handling and management."227 The Commission could convert the recently dissolved County Land Management Boards ${ }^{228}$ into committees in each county that work together with community members to promote women's participation in land dispute settlements and mandate trainings for people who participate in any land dispute resolution methods. ${ }^{229}$ The members of County Land Management Boards are already familiar to the county governments; therefore, this would both continue the Boards' important work and improve coordination on discrimination matters with the county governments.

Organizations in Kenya, such as KELIN (Kenya Legal and Ethical Issues Network on HIV \& AIDS), have proven training models to educate populations in women's rights, land rights, and women's participation in TDRMs. The National Land Commission and CECs can work together with these organizations or adapt their training methods to both educate the community and change perceptions. For instance, KELIN works to return family land to widows. Before the organization takes any measures, they have a dialogue with both the elders and the widows to ensure buy-in from both groups to make longerlasting solutions. ${ }^{230}$ As a result of their efforts, the number of female elders has tripled in

224 See generally Kenya Land Alliance, supra note 165; Women, Land and Property Rights, KELIN, http://www.kelinkenya.org/women-land-and-property-rights/ [https://perma.cc/BKJ6-9FZB].

225 Ezer, supra note 30, at 76.

226 Constitution art. 60(e)-(f) (2010) (Kenya).

227 National Land Commission Act (2015) Cap. 5D $\S 5$.

228 See supra note 24 and accompanying text.

229 National Land Commission Act (2015) Cap. 5D $\S 16$ (granting the Commission the power to instate committees to handle land matters at the county level).

230 Ezer, supra note 30, at 77-78 (stating that KELIN talks with the community "to identify core community values and the practices that should apply" to dispute resolutions and remedies). 
the communities in which they work. ${ }^{231}$ Other organizations, such as the Kenyan Land Alliance, employ simple legal training for elders, chiefs, and women, which has helped to dramatically shift perspectives. ${ }^{232}$ These successes have created a growing culture of inclusion that can radically shift the trajectory of land dispute resolution mechanisms if they are implemented across forums and supported by government officials.

\section{Preventing Discrimination in Stage Two: Adjudication and Registration}

The Land Adjudication Act and the "adjudication programme," to be created by the Cabinet Secretary, will govern the second stage of community land. ${ }^{233}$ The program should clarify that the residents who participate in the Land Adjudication Committee are also "appointees," because they are "appoint[ed]" by the adjudication officer (an official of the National Government). ${ }^{234}$ These committees would, therefore, be subject to the constitutional prohibition on appointive body having more than two-thirds of its membership be one gender. ${ }^{235}$ This is vital because "[h]aving women in visible leadership positions has a positive impact for improving both women's and men's views on the capabilities of women as community leaders and improving justice outcomes for women." ${ }^{236}$ This solution may not be entirely sufficient however, because the Kenyan Parliament's two-thirds gender rule

231 Id. at 84 (stating women elders now compose a quarter to two-thirds of all elders in the communities with which they work).

232

When her husband did not support their children and sold the family's land, Sadera was forced to rent land from neighbors to feed her family. She met with the elders more than 10 times hoping that they could ensure her husband supported the children. Each time she was unsuccessful, until she learned about her legal rights. Sadera went back to the assistant chief, who had also received KJP training. With his and the elders' new understanding of the law and their role in upholding it, the elders did something different: They ordered Sadera's husband to support his family by returning land to his wife.

Boudreaux, supra note 103.

233 Community Land Act, No. 27 (2016) Kenya Gazette Supplement No. $148 \S \S 8,46(6)$.

234 Land Adjudication Act (2016) Cap. $284 \S 6$ (1) ("In respect of each adjudication section, the adjudication officer, after consultation with the District Commissioner of the district within which the adjudication section lies, shall appoint not less than ten persons resident within the adjudication section to be the adjudication committee for that adjudication section.").

235 Constitution art. 27(8) (2010) (Kenya).

236 International Development and Law Organization, Accessing Justice: Models, Strategies and Best Practices on Women's Empowerment 32 (2013), http://www.idlo.int/sites/default/files/WomensAccess toJusticeFullReport.pdf [https://perma.cc/W5MJ-7M2F]. 
has only increased the number of women in Parliament to nineteen percent. ${ }^{237}$ Nevertheless, this change, in conjunction with the trainings for the elders and the community, can start to produce results where women are included in TDRMs and other institutions.

\section{Eliminating Discrimination in Stage Three: Registered Community Land}

The Community Assembly and the Community Land Management Committee control land dispute resolution in registered communities. While these dispute resolution systems are not perfect, improvements to registered community land dispute resolution should not involve a repeal of the powers given to communities. Article 61(1) of the Constitution provides that "[a]11 land in Kenya belongs to the people of Kenya collectively as a nation, as communities and as individuals." ${ }^{238}$ The Supreme Court has stated, "it is mandatory to involve the people in the decision-[]making process, regarding such a valuable national resource as land." ${ }^{239}$ The Community Land Act signals a vital and significant step toward realizing this constitutional mandate. Solutions, therefore, should involve methods that widen participation to include and promote those typically not included, such as women and youth.

TDRM practices have developed over a significant period and have worked well for communities - trainings and small changes to the laws that formalize TDRMs could provide a sufficient base for communities to create their own change. ${ }^{240}$ On a very broad scale the Supreme Court or the legislature needs to clarify that the just constraints on TDRMs in Article 159 include equality of participation. ${ }^{241}$ This would be one far-reaching

237 Helen Mudora Obande, Association of Media Women in Kenya, Forward, in 86 And Counting: Women Leaders in the 11th Parliament (2015).

238 Constitution art. 61(1) (2010) (Kenya).

239 National Land Commission v. Attorney-General (2014) S.C.K. Advisory Opinion No. 2, paras. 337 (Kenya).

Where, for example, land access for all customary group members is relatively secure and equitable, available forms of investment are recognized and protected, local land conflicts are infrequent, environmental resources are abundant and outside encroachment does not threaten cultural survival or livelihood security, there is little need for State intervention or regulation because the policy objectives of that regulation - social justice, economic security, environmental conservation — are being satisfied by customary structures themselves.

Fitzpatrick, supra note 201, at 471.

241 Constitution art. 159(3)(b) (2010) (Kenya). 
step in legitimizing women's participation in different types of TDRMs. At the registered community land level, the legislature should clarify that through the formalization of TDRMs in Section 15 of the Community Land Act, the Community Land Management Committees are also subject to Article 159 and the two-thirds gender rule. ${ }^{242}$

While scholars in women's land rights in Kenya state that, "law alone is not the solution unless it is combined with enforcement," 243 the work of organizations such as Kenya Land Alliance (KLA) and KELIN demonstrates that social changes and trainings can create bottom-up approaches that affect processes without legal enforcement. Solutions that combine both the legal legitimization of women's participation in TDRMs and social changes through trainings can go a long way in empowering communities to make their own changes. The spirit of the Constitution calls for Kenya to re-forge itself through public participation - changes in formalized TDRMs should happen through the participation of all Kenyan citizens.

\section{CONCLUSION}

Kenya is at a unique crossroads. The new Constitution and subsequent land legislation in Kenya have formalized TDRMs, thereby entrenching discrimination because women are not traditionally part of these land dispute resolution processes. The new legislation has also created a moment of institutional fluidity: the confluence of the many dispute resolution forums and the interconnecting actors create a unique context that is ripe for change and solutions through public participation and law. There are points of intervention for these changes at each stage of community land management and dispute resolution. Because of this moment of institutional fluidity, the changes that are made now will shape future land dispute resolutions processes across the country. To ensure equality of both participation and outcome, these changes to the institutional structure must include women and other marginalized groups.

Changes and institutional growth are not unique to Kenya. Other countries around the world experience both a confluence of forums and interconnecting decision-makers across formal and informal space. The theory of institutional fluidity can help to change the dialogue about path dependency and the formal/informal dichotomy to elucidate the interdependence of TDRMs and formal law. The theory also offers an optimistic lens

242 Id. art. 27(8).

243 Sandra F. Joireman, The Mystery of Capital Formation in Sub-Saharan Africa: Women, Property Rights and Customary Law, 36 World Dev. 1233, 1242 (2008). 
through which to view institutions: change is both probable and encouraged. Finally, it creates a dialogue around solutions to institutional issues that gives equal importance to legal and social contexts, community movements, and legislative change. Understanding complex contexts is a first step toward creating positive change that both upholds each constituent's role in change-making and opens institutional doors to marginalized groups. 